\title{
IMPACT OF E-COMMERCE ON BRAND LOYALTY AND BRAND SWITCHING BEHAVIOUR OF CONSUMARS OF ELECTRONIC PRODUCTS: A STUDY
}

\author{
Y.V.Sujana ${ }^{1}$ \\ Research Scholar,Dept. of Management,Rayalseema University, Kurnool. \\ Prof. G.L.Narayanappa ${ }^{2}$ \\ Research Supervisor and Dean,School of Commerce and Mgt.Dravidian University, Kuppam.
}

Article DOI: $\underline{\text { https://doi.org/10.36713/epra4559 }}$

\begin{abstract}
In recent times, tastes and preferences are consistently changing on purchase behaviour. In the year 2018, around 120 million people made their purchases over the internet and the number expected to reach 175 million by $2020 . \quad$ The demand potential of e-commerce made private equity firms to look for it. The government has an attractive policy for ecommerce. The government policy allows the $100 \%$ FDI (Foreign direct investment) in B2B model of e-commerce and 100 per cent FDI also allowed in market place model through automatic route.

E-commerce gives benefits to society, customer and organisations. E-Commerce to Society: E-commerce is one of the largest employment generators in India. It reduces the regional imbalances and makes all levels of customers access the product at their fingertips. It eliminates the intentional bias of the sellers so that it saves the customer. ECommerce to Consumers: Customer can access a wide range of products or services at their fingertips. E-commerce gives zero movement of truth and the first movement of truth for the customers. Customer reviews next to the product on e-commerce site offers mirror purchase experience for customers so that customers avoid the counterfeit products. It provides convenience and also saves time and money. E-Commerce to organisations: Technology makes the organisations independent. E-commerce reduces salespersons' dependence. It abolishes the geographical boundaries of the business. It reduces the cost of sale. It can fetch the precise statistics over the sales, thereby strengthen the business strategies.
\end{abstract}

KEYWORDS: E-commerce, Customer reviews, Foreign direct investment, electronic products

\section{INTRODUCTION}

In recent times, tastes and preferences are consistently changing on purchase behaviour. In the year 2018, around 120 million people made their purchases over the internet and the number expected to reach 175 million by 2020. The demand potential of ecommerce made private equity firms to look for it. The government has an attractive policy for e-commerce.
The government policy allows the $100 \%$ FDI (Foreign direct investment) in $\mathrm{B} 2 \mathrm{~B}$ model of e-commerce and 100 per cent FDI also allowed in market place model through automatic route.

E-commerce gives benefits to society, customer and organisations. E-Commerce to Society: Ecommerce is one of the largest employment generators in India. It reduces the regional imbalances and makes 


\section{EPRA International Journal of Research and Development (IJRD)}

all levels of customers access the product at their fingertips. It eliminates the intentional bias of the sellers so that it saves the customer. E-Commerce to Consumers: Customer can access a wide range of products or services at their fingertips. E-commerce gives zero movement of truth and the first movement of truth for the customers. Customer reviews next to the product on e-commerce site offers mirror purchase experience for customers so that customers avoid the counterfeit products. It provides convenience and also saves time and money. E-Commerce to organisations: Technology makes the organisations independent. Ecommerce reduces salespersons' dependence. It abolishes the geographical boundaries of the business. It reduces the cost of sale. It can fetch the precise statistics over the sales, thereby strengthen the business strategies.

\section{STATEMENT OF THE PROBLEM}

"E-commerce had a considerable impact on how business is conducted. It has affected consumers, the value chain, markets and business models." Internet and smartphone demanded the customer to transform from offline to online shopping. E-commerce for the year 2017 has registered 38.5 US \$ billion market value, $2018 \mathrm{~F}$ yeas 50.0 US $\$$ billion, $2020 \mathrm{~F}$ year 63.7 US \$ billion, $2022 \mathrm{~F}$ year 150.0 US $\$$ billion and $2026 \mathrm{~F}$ year 200.0 US $\$$ billion. Hence, the present research is undertaken on impact of e-commerce on purchase behaviour of electronic products. The specific problems raised in the present research include: What is the source for e-commerce awareness. Can the e-commerce change the perceptions of electronic products?. What is the impact of e-commerce on purchase behaviour of electronic products? How the e-commerce influence the post purchase behaviour of electronic products.

\section{SELECT REVIEW OF LITERATURE}

The existing studies concerning the awareness of e-commerce, impact of e-commerce on perceptions of electronic products, impact of e-commerce on purchase and post purchase behaviour of electronic products are reviewed;

Silky Vigg Kushwah1 and Anjali Singh (2019) research on "From traditional shopping to online shopping a study of the paradigm shift in consumer behaviour" stated seller's image, concern for customer and website quality as the influential factors of the online shopping. Manisha and Shukla (2016) article on "An analysis of consumer behaviours towards online shopping of electronic goods with special reference to Bhopal and Jabalpur City" and stated that cash on delivery, product price, quality, accessibility, time convenience, discounts and promotions and shop anywhere and anytime of ecommerce influence the purchase attitude of electronic products. Upasana, Naveen and Abhishek (2015) in their research article on "A study of online purchase behaviour of customers in India" acknowledged that return, delivery services and refund policy of online store influence the purchase behaviour.

Subhalakshmi and Ravi (2015) study on "The impact of perceived risk on the online shopping attitude of cosmetic products in Tirunelveli City" have extracted three different types of risks for online shopping: financial risk, information risk and time risk. Sanjay Kumar (2015) article on "Online shopping - a literature review" stated social contact, convenience, diversity and information seeking as the influential factor of online shopping. Riaz and Raman (2015) research on "The emerging trend of online shopping: a literature review" affirmed that online customer can attain the knowledge of product quality, product specifications, price easily, and availability than traditional customer.

Li et al. (2015) study on "The interplay between value and service quality experience: e-loyalty development process through the eTailQ scale and value perception" explored the e-loyalty factors and also validated the e-service quality scale "eTailQ scale". The research claims eTailQ scale dimensions as: security, website design, customer support and reliability. Korina C. Pinca and Legaspi (2015) article on "Online shopping behavior of students in the college of business administration: basis for enriching content of the subject matter" revealed that female students are more preferred online shopping than female students. Kavitha and Muthumani (2015) research on "The Impact of demographic variables based on buying behaviour intention towards e-store in India" have explored the impact of demographic factors on online shopping. The research claims male and 2630 age groups as the potential demographics for online shopping.

Hemani and Manjit Kaur (2015) article on "Consumers' behaviour towards online purchases" claims online purchase experiences, safety of payment, product perception, and customer service as the as the influential factors of online shopping. Harjot and Daljit (2015) research on "E-commerce in Indiachallenges and prospects" acknowledged fear as the greatest obstacle of online payment in India. Cheah et al (2015) have explored the "Factors influencing consumers' attitudes and purchase intentions of edeals" and identified three different types of factors for online consumer attitude; vendor and product 


\section{EPRA International Journal of Research and Development (IJRD)}

characteristics, channel characteristics and consumer characteristics.

\section{NEED FOR THE STUDY}

Reason for selection of topic: In recent times, customers' tastes and preferences are consistently changing in Indian. In the year 2018, around 120 million people made their purchases over the internet and the number expected to reach 175 million by 2020 . The demand potential of e-commerce made private equity firms to look for it. The government has an attractive policy for e-commerce. The government policy allows the 100 per cent foreign direct investment in B2B model of e-commerce and 100 per cent FDI also allowed in market place model through automatic route. E-commerce gives benefits to society, customer and organisations. In India, Ecommerce expected to reach US $\$ 200$ billion by 2026 . Hence, the present study will help for electronic product organizations to tap the potential market. The research is helpful for academicians to understand about the impact of e-commerce on purchase behaviour electronic products. For marketing practitioners it is useful to formulating strategies for e-commerce purchase of electronic product. Hence, there is a need to undertake a research on impact of e-commerce on purchase behaviour electronic products.

\section{OBJECTIVES OF THE STUDY}

The specific objectives formulated for this study are:

I. To study the concept of e-commerce and theoretical aspects of consumer purchase behaviour of electronic products;

II. To examine the awareness and perception of customers on e-commerce;

III. To analyze the impact of e-commerce on purchase behaviour of electronic products;

IV. To assess the impact of e-commerce on post purchase behaviour( satisfaction \& loyalty) of electronic products and

V. To offer suitable suggestions for further improvements of electronic products purchase behaviour.

\section{RESEARCH FINDINGS}

- The highest, 270 respondents are the satisfied buyers followed by 192 respondents are habitual buyers and switchers, 68 respondents are linkers of the brand and 56 respondents are committed buyers. Time lag between the purchase and availability of more no. of brands made them habitual buyers and switchers majorly.

- Out of 586, the highest, 83.95 stated that ecommerce contributes for brand switch behaviour of electronic products and 16.04 percent stated that e-commerce can enhance the brand loyalty of electronic products. Majority 64.89 percent of the customers stated that by selling all verities of same brand e-commerce enhance the customer loyalty and rest 35.10 percent are stated other reasons.

- To the statement "New models of electronic products comes very often in e-commerce hence I will change electronic brands frequently", out of 492 respondents, 2.0 percent are disagreed, 22.4 percent are agreed, 2.6 percent are strongly disagreed, 6.3 percent are neutral and 66.7 percent are strongly agreed.

- For the statement "Large variety of brands on e-commerce site makes the customer to choose different brands", the highest, 68.3 percent are agreed followed by 26.6 percent are strongly disagreed, 2.8 percent are strongly agreed, 1.6 percent are neutral and 0.6 percent are disagreed.

- Out of the 492 customers, 1.2 percent are disagreed, 32.3 percent are strongly disagreed, 1.4 percent are neutral, 62.4 percent are agreed and 2.6 percent are strongly agreed to the statement "Time lag between the purchases of electronic product on e-commerce makes the customer to switch the brand."

- The highest, 18.5 percent are strongly disagreed, 37.0 percent are disagreed, 30.5 percent are neutral, 9.8 percent are agreed and 4.3 percent are strongly agreed to the statement "Offers/ Discounts of e-commerce make the customer to switch the electronic brands".

- The highest, 62.8 per cent are agreed to the statement "Price variants of brands on ecommerce make the customer to switch the electronic brands" followed by 29.9 percent are disagreed, 4.1 percent are strongly agreed, 1.8 percent are neutral and 1.4 percent are strongly disagreed.

- The rotated component matrix shows the two influential factors of e-commerce on brand switch behaviour of electronic products and the two factors are:

Factor -1: Promotions (Discounts and Offers) 


\title{
EPRA International Journal of Research and Development (IJRD)
}

Factor-2: Decoy effect

\section{SUGGESTIONS}

In the light of the findings arrived earlier, the following measures were suggested;

- Majority of sample respondents acknowledged that they aware the ecommerce products through digital media like search engine, social media and so on. Hence, electronic product organizations have to consider digital media as awareness media.

- E-commerce promotions are changing the perception of customers. This fact is acknowledged by most of the sample respondents. Hence, it is advised to electronic product organizations along with their own promotions have to collaborate with the promotions of e-commerce sites.

- E-commerce is influencing the purchase behaviour of electronic products through: promotions (discounts and offers); product assortment; convenience and fraudulent behaviour. Hence, it can be advised to electronic product organisations to select the -ecommerce businesses which exhibit the above characteristics.

- The conclusion that it can draw from the study is that e-commerce is influence the satisfaction of electronic products through it's; mirror purchase experience, convenience and promotions. Therefore, electronic product organizations companies should ensure the good ratings and reviews on the e-commerce site and has to focus on offers, discounts of its products.

- The research reveals that e-commerce causes the brand switch behaviour of electronic products through decoy effect and promotions (discounts and offers). Hence, it can be advised to electronic product organisations to focus more product variants and offers/ discounts in order to avoid brand switch behaviour.

- Sales promotion still remains an important factor of purchase of products on ecommerce site. Hence, it can be suggested electronic product organizations must inculcate sales promotion in their strategy towards purchase behaviour of consumer.

- Electronic product organisations should device a feedback mechanism for customer reviews and ratings to products modifications and new product development and it should be made an integral part of the research and development process of the organization.

- It is an acknowledged truth that, product cannot attain a good reputation through offers, discounts. The product quality vital for it hence it can be suggested that electronic product organisations along with the offers, discounts has to maintain proper quality of products.

- Along with financial aspects e-commerce sites, electronic product companies should also focus on the right relationship with the e-commerce sites for long term business success.

- Electronic products tastes and preferences change from time to time. Hence, electronic product organisations should introduce the new brand to increase its market share.

\section{REFERENCES}

1. Silky Vigg Kushwahl and Anjali Singh (2019). From traditional shopping to online shopping a study of the paradigm shift in consumer behaviour. Journal of General Management Research, Vol. 6, Issue 1, January 2019, pp. 1-13

2. ManishaKinker and N.K. Shukla, "An Analysis of Consumer Behaviours towards Online Shopping of Electronic Goods with Special Reference to Bhopal and Jabalpur City", International Journal of Innovation and Applied Studies, Vol. 14, No. 1, January 2016, p. 218.

3. UpasanaKanchan, Naveen Kumar, and Abhishek Gupta, "A Study of Online Purchase Behaviour of Customers in India”, ICTACT Journal on Management Studies, Vol. 1, Issue. 3, August 2015, p. 136.

4. Subhalakshmi, R., and Ravi, P. (2015). The Impact of Perceived Risk on the Online Shopping Attitude of Cosmetic Products in Tirunelveli City. International Journal of Scientific Research, January, Vol.4 (1), pp.231-233.

5. Sanjay Kumar, "Online shopping - A Literature Review", Proceedings of National Conference on Innovative Trends in Computerscience Engineering held at BRCMCET, Bahal on 4th April 2015, p. 129.

6. ArikaRiaz and Saravanan Raman, "The Emerging Trend of Online Shopping: A Literature Review”, International Journal of Accounting, Business and Management, Vol. 1, No.1, April 2015, p. 2.

7. Liu, X., He, M., Gao, F., \& Xie, P. (2008). An empirical study of online shopping customer satisfaction in China: a holistic perspective. 
International Journal of Retail \& Distribution

Management, 36(11), 919-940.

8. Korina C. Pinca and Legaspi (2015). Online Shopping Behavior of Students in the College of Business Administration: Basis for Enriching Content of the Subject Matter. International Journal of Education and Research, January, Vol.3 (1), pp.333-348.

9. KavithaRajajogan and Muthumani, "The Impact of Demographic Variables Based on Buying Behaviour Intention towards E-store in India", Journal of Theoretical and Applied Information Technology, Vol. 75, No. 1, May 2015, p. 65.

10. Hemani Malhotra and Manjit Kaur Chauhan, "Consumers' Behaviour Towards Online Purchases”, International Journal of English Language, Literature and Humanities, Vol. 2, Issue.9, January 2015, p. 398.

11. Harjot Kaur and Daljit Kaur, "E-commerce in India- Challenges and Prospects", International Journal of Engineering and Technologies, Vol. 1, Issue. 2, March-April 2015, p. 37.

12. Cheah I., Phau I., Liang J. (2015), "Factors influencing consumers' attitudes and purchase intentions of e-deals", Marketing Intelligence \& Planning, Vol. 33 No. 5, pp. 763-783. 